\title{
PERAN STRATEGI METAKOGNITIF DENGAN BANTUAN METODE PQ4R PADA PRESTASI AKADEMIK MAHASISWA PIAUD DI INSTITUT AGAMA ISLAM SUNAN GIRI BOJONEGORO
}

\author{
Eshthih Fithriyana \\ IAI Sunan Giri Bojonegoro \\ Eshthih.Fithriyana@gmail.com
}

\begin{abstract}
Abstrak
Penelitian ini merupakan penelitian studikasus yang menganalisis secara komprehensif tentang peran strategi metakognitif dengan bantuan metode PQ4R pada prestasi akademik mahasiswa PIAUD di Institut Agama Islam Sunan Giri Bojonegoro. Mahasiswa dalam hal ini mahasiswa pendidikan anak usia dini sebagai penerima proses pembelajaran di perguruan tinggi dituntut untuk membekali diri dengan kompetensi terstandar yang diwujudkan dengan prestasi akademik, sebagai bekal untuk mengambil posisi dan berperan dalam dunia kerja yang semakin kompetitif. Berdasarkan hasil analisis data wawancara, observasi dan angket menunjukan bahwa penggunaan strategi metakognitif dengan bantuan metode PQ4R memiliki peran yang signifikan pada prestasi akademik mahasiswa terutama pada mata kuliah kognitif.
\end{abstract}

Kata Kunci: Metakognititf, Metode PQ4R, Prestasi Akademik

\section{Abstract}

'This study is a study study that analyzes the role of metacognitive strategies with the help of the PQ4R method on academic achievement of PIAUD students at the Sunan Giri Bojonegoro Institute of Islamic Religion. Students in this case are students who follow the learning process in higher education who are required to equip themselves with standardized competencies created with academic achievement, as a provision to take positions and support in an increasingly competitive world of work. Based on the results of data analysis of interviews, observations and questionnaires showed that the use of metacognitive strategies with the help of the PQ4R method had a significant role in student academic achievement in cognitive courses.

Keywords: Metacognitivity, PQ4R Method, Academic Achievement 


\section{PENDAHULUAN}

Kebutuhan manusia akan pendidikan merupakan kebutuhan asasi dalam rangka mempersiapkan setiap insan manusia sampai pada suatu tingkat di mana mereka mampu menunjukkan kemandirian yang bertanggung jawab, baik terhadap dirinya maupun terhadap lingkungannya. Bermuara pada satu pandangan bahwa melalui pendidikan, manusia membuktikan diri sebagai makhluk yang terus berkembang. Melalui pendidikan manusia berkembang dari sebelumnya hanya memiliki potensi yang belum memiliki arti apa-apa, tetapi dengan pendidikan mereka berkembang menjadi lebih sempurna dan terus menyempurnakan diri.

Bagaimanapun juga, manusia membutuhkan perantara untuk terjadinya sebuah pendidikan. Perantara tersebut dapat berupa lingkungan keluarga, lingkungan masyarakat tempatnya tinggal maupun sebuah instansi pendidikan seperti sekolah maupun perguruan tinggi. Berdasarkan pendapat Munib (dalam Pantiwati, 2015:27) bahwa lingkungan dapat diartikan sebagai kesatuan ruang suatu benda, daya, keadaan dan makhluk hidup termasuk manusia dan perilakunya yang mempengaruhi keberlangsungan peri kehidupan dan kesejahteraan manusia serta makluk hidup lainnya. ${ }^{1}$

Perguruan Tinggi merupakan satuan pendidikan yang menyelenggarakan pendidikan tinggi, dapat berbentuk: pendidikan akademi, Politeknik, Sekolah Tinggi atau Universitas. Pemerintah, departemen lain, atau masyarakat, menyelenggarakan pendidikan, sehingga dapat membentuk kualitas manusia dari segi akademik maupun kepribadi. ${ }^{2}$

Peran perguruan tinggi sangat dipengaruhi oleh: peran penyelenggara yang terdiri dari pemerintah, yayasan, dan pimpinan perguruan tinggi; sivitas akademika yang terdiri dari: dosen dan mahasiswa, serta sarana-prasarana. Semuanya merupakan system terpadu dalam penyelenggaraan PT.

Seorang manusia dalam hal ini para mahasiswa perlu memperlihatkan eksistensinya sebagai makhluk sosial dalam hal membangun kualitas diri demi dirinya sendiri maupun demi bangsa dan negaranya. Apalagi dengan diberlakukannya era perdagangan bebas, tingkat persaingan global di segala sektorpun mengalami peningkatan.

Mahasiswa dalam hal ini mahasiswa pendidikan anak usia dini sebagai penerima proses pembelajaran di perguruan tinggi dituntut untuk membekali diri dengan kompetensi terstandar yang diwujudkan dengan prestasi akademik, sebagai bekal untuk mengambil posisi dan berperan dalam dunia kerja yang semakin kompetitif dan tentu saja dengan perannya sebagai calon pendidik anak usia dini.

\footnotetext{
${ }^{1}$ Pantiwati, Y. (2015). Pemanfaatan Lingkungan Sekolah sebagai Sumber Belajar dalam Lesson Study untuk Meningkatkan Metakognitif. Malang: Jurnal BIOEDUKATIKA Vol. 3 No. 1 Mei 2015 ISSN: 2338-6630 | Halaman 27-32

2 Arifin, M. (2017). Strategi Manajemen Perubahan Dalam Meningkatkan Disiplin Di Perguruan Tinggi.Medan: Jurnal EduTech Vol. 3 No. 1 Maret 2017 ISSN: 2442-6024, hal 127
} 
Anak usia dini adalah anak yang berada pada masa kritis dalam kehidupannya. Karena pada usia 0 sampai 6 tahun seseorang mengalami perkembangan yang sangat pesat. Hal tersebut sejalan dengan penelitian yang dilakukan oleh Baylor College of Medicine (dalam Wahyudin, 2012:2) mengemukakan bahwa sekitar 50\% kapabilitas kecerdasan manusia terjadi ketika anak berusia 4 tahun, $80 \%$ telah telah terjadi ketika berusia 8 tahun, dan mencapai titik kulminasi ketika anak berusia 18 tahun. Jadi perkembangan yang terjadi pada kurun waktu 4 tahun pertama, sama besarnya dengan perkembangan yang terjadi pada kurun waktu 14 tahun berikutnya, dan selanjutnya perkembangan otak akan mengalami stagnasi. Itulah sebabnya periode tersebut disebut dengan periode emas atau the golden age.

Berdasarkan penelitian tersebut kita dapat melihat betapa penting peran seorang guru di pendidikan anak usia dini. Karena pendidik PAUD harus memiliki kuwalifikasi dan kualitas dalam memanfaatkan momen yang penting bagi anak, agar anak usia 0-6 tahun mampu mengembangkan seluruh aspek perkembangannya secara optimal. Sehingga sebelum mahasiswa terjun kedalam dunia pendidik PAUD hendaknya mahasiswa membekali dirinya dengan pengetahuan yang optimal yang dalam hal ini ditunjukan dengan prestasi akademik.

Untuk itu perlu adanya kualitas pendidikan tinggi yang baik. Dosen diperguruan tinggi harus dapat memenuhi kualifikasi dan kompetensi, serta jeli dalam mempersiapkan pembelajarannya. Agar tujuan dari proses belajar dan mengajar dengan mahasiswa terwujud secara optimal. Salah satunya yaitu terlebih dahulu memahami dengan seksama hal-hal yang berhubungan dengan proses belajar mengajar. Seperti penggunaan strategi pembelajaran, metode pembelajaran, melaksanakan kerangka pembelajaran yang tepat, media pembelajaran dan juga materi yang akan disampaikan pada hari itu.

Selain itu mahasiswa terutama sebagai calon guru juga harus memiliki kemampuan berfikir yang tinggi. Kemampuan berfikir tingkat tinggi khususnya metakognisi adalah kemampuan krusial yang harus dimiliki oleh seorang calon guru. Metakognisi bermakna berfikir tentang pemikiran dan merupakan suatu proses yang terdiri dari proses penilaian sendiri tentang tahap pengetahuan, usaha ketika merancang, menukar strategi, serta penilaian pelaksanaan tugas yang dijalankan. Semakin tinggi kemampuan metakognitif seorang mahasiswa, maka tingkat keberhasilan belajarnya juga semakin tinggi. Tingkat keberhasilan belajar seorang mahasiswa, dapat dipengaruahi oleh pengalaman belajar. Sikap seseorang terhadap pembelajaran dapat ditentukan oleh usia. Semakin tinggi usia seseorang, maka pengalaman belajarnya juga akan semakin bertambah, seperti ketika dia menemukan beberapa kendala dan permasalahan dalam belajar. Ketika hal tersebut terjadi, maka seorang mahasiswa akan dituntut untuk dapat mengatasi masalah belajarnya tersebut secara mandiri, sehingga dia akan berusaha memikirkan apa solusi yang harus diambil dalam memecahkan permasalahannya itu dan strategi belajar apa yang seharusnya digunakan agar suatu konsep pembelajaran dapat dia 
kuasai dengan baik. Kemampuan berpikir bagaimana cara belajar ini adalah kemampuan metakognisi yang merupakan bagian dari kemampuan berpikir tingkat tinggi.

Pencapaian kemampuan metakognisi mahasiswa Pendidikan PAUD semester 6 Fakultas Tarbiyah IAI Sunan Giri Bojonegoro Tahun Pelajaran 2018/2019, sejauh ini ini belum berkembang secara optimal.. Dari pengamatan dan interaksi yang dilakukan dengan Mahasiswa Program Studi Pendidikan Anak Usia Dini, dapat dilihat beberapa gejala yang menunjukkan rendahnya motivasi belajar mahasiswa. Dari dalam dirinya sendiri, mahasiswa belum mampu membangkitkan semangat dan motivasi belajarnya, begitu juga motivasi yang diberikan oleh dosen dalam setiap perkuliahan, dirasakan kurang berkesan oleh mahasiswa. Kehadiran mahasiswa di kampus terkesan hanya sebatas memenuhi tuntutan kuliah. Terhadap perubahan yang terjadi di kampus, terutama perubahan dalam meningkatkan mutu pendidikan, mahasiswa kurang merespon dengan baik.

Materi perkuliahan Program Studi Pendidikan PAUD IAI Sunan Giri Bojonegoro, berkaitan antara satu dengan yang lainnya, tetapi pada kenyataannya mahasiswa kurang mampu menerapkan ilmu yang sudah pernah didapatkan sebelumnya dalam mata kuliah lanjutan. Hal tersebut menunjukkan bahwa, usaha untuk belajar sebagaimana mestinya, serta kemampuan mahasiswa dalam berfikir tentang kelemahannya dalam belajar dan menemukan solusi yang tepat, masih sangat kurang.

Kemampuan metakognisi sangat penting dimiliki oleh seorang calon guru. Berdasarkan pendapat Flavell (dalam Fitri, 2017: 46) bahwa metakognitif merupakan pengetahuan seseorang mengenai proses berpikir dan hasil berpikirnya atau apapun yang berkaitan dengan proses dan hasil berpikir tesebut. Selain itu Flavell menjelaskan bahwa metakognisi sebagai pengetahuan tentang objek-objek kognitif, yaitu tentang segala sesuatu yang berhubungan dengan kognisi. ${ }^{3}$

Untuk mengetahui efektifitas penggunaan strategi metakognitif dalam meningkatkan kemampuan akademik mahasiswa maka penulis tertarik untuk melakukan penelitian ini.

Seperti yang pernah dilakukan oleh penelitian sebelumnya yaitu Yuni Tri Kasyani 2012, yang berjudul Efektivitas Strategi Metakognisi terhadap Keterampilan Berpikir pada Pelajaran Fisika di SMA Negeri 6 Balikpapan. Hasil yang diperoleh dalam penelitian itu bahwa 1) keterampilan berpikir siswa berkemampuan awal tinggi, yang belajar dengan strategi metakognisi lebih tinggi dibandingkan dengan siswa yang belajar secara konvensional, 2) keterampilan berpikir siswa berkemampuan awal rendah yang belajar dengan strategi metakognisi lebih tinggi dibandingkan dengan siswa yang belajar secara konvensional, 3) keterampilan berpikir siswa berkemampuan awal tinggi lebih tinggi dibandingkan dengan siswa berkemampuan awal rendah yang belajar dengan strategi metakognisi.

${ }^{3}$ Fitri,M. (2017). Metakognitif Pada Proses Belajar Anak Dalam Kajian Neurosains.Surabaya: Jurnal Pendidikan Volume 2 Nomor 1 Tahun 2017 Halaman: 44-52 e-ISSN: 2527-6891. 
Penelitian tentang penggunaan strategi Metakognitif juga pernah dilakukan Suesti Restuadyani (2015), yang berjudul Efektivitas Strategi Metakognitif Berbantuan Isomorphic Problems terhadap Kemampuan Pemecahan Masalah Fisika Ditinjau dari Kemampuan Metakognitif Siswa Kelas X. Hasil yang diperoleh dalam penelitian itu adalah (1)Kemampuan pemecahan masalah peserta didik berbeda secara signifikans dibanding yang dibelajarkan dengan pendekatan problem based learning. Hasil anava dua jalur menunjukkan bahwa sig. besarnya 0,000 kurang dari 0,05, (2)kemampuan pemecahan masalah peserta didik ditinjau dari kemampuan metakognitif rendah kelas eksperimen lebih tinggi dibanding kelas kontrol. Hasil anava dua jalur menunjukkan bahwa sig. besarnya 0,000 kurang dari 0,05, (3) kemampuan pemecahan masalah peserta didik ditinjau dari kemampuan metakognitif rendah kelas eksperimen lebih tinggi dibanding kelas kontrol. Hasil anava dua jalur menunjukkan bahwa sig. besarnya 0,000 kurang dari 0,05,(4)Strategi metakognitif berbantuan isomorphic problem efektif terhadap kemampuan pemecahan masalah, perbedaan yang signifikan antara kemampuan pemecahan masalah ditinjau dari kemampuan metakognitif tinggi dan rendah antara kelas eksperimen dan kontrol. Atas dasar itulah maka penulis mengambil judul penelitian, "Efektifitas Strategi Metakognitif dengan Bantuan Metode PQ4R Terhadap Kemampuan Akademik Ditinjau dari Kemampuan Metakognitif Mahasiswa PAUD IAI Sunan Giri Bojonegoro Tahun Pelajaran 2018/2019”.

\section{PEMBAHASAN \\ PRESTASI AKADEMIK}

Menurut kamus besar Indonesia (2005) prestasi adalah hasil yang telah dicapai (dari yang telah dilakukan, dikerjakan, dan sebagainya. Sedangkan prestasi belajar adalah penguasaan pengetahuan dan keterampilan yang dikembangkan oleh mata pelajaran, lazimnya ditunjukan dengan nilai tes atau nilai yang diberikan oleh guru.

Menurut Winkel (dalam Diana, 2011:12) menyebutkan bahwa prestasi belajar siswa satu dengan yang lainnya tidak sama, perbedaan ini disebabkan oleh banyak faktor. Sanjaya (2006) menyatakan bahwa faktor-foktor yang menyebabkan perbedaan keberhasilan dalam belajar yang meliputi faktor internal dan eksternal.

Sedangkan prestasi akademik menurut Sobur (dalam Sahputra, 2006) adalah perubahan dalam hal kemampuan yang disebabkan karena proses belajar. Bentuk hasil proses belajar dapat berupa pemecahan tulisan atau lisan, keterampilan dan pemecahan masalah yang dapat diukur dan dinilai dengan menggunakan tes yang terstandar.

\section{STRATEGI PEMBELAJARAN}

Berdasarkan pendapat Dick dan Carey (2005:7) strategi pembelajaran adalah komponen-komponen dari suatu set materi termasuk aktivitas sebelum pembelajaran, dan partisipasi peserta didik yang merupakan prosedur pembelajaran yang digunakan kegiatan 
selanjutnya. ${ }^{4}$ Dick dan Carey juga menjelaskan bahwa strategi dan desain pembelajaran merupakan komponen-komponen umum dari suatu bahan pembelajaran dari prosedurprosedur yang akan digunakan dalam pembelajaran untuk mengahasilkan hasil belajar tertentu. Menurut mereka strategi pembelajaran bukan hanya terbatas prosedur atau tahapan kegiatan belajar saja, melainkan termasuk juga pengaturan materi atau paket program pembelajaran yang akan disampaikan kepada peserta didik.

${ }^{5}$ Dilihat dari strateginya, pembelajaran dapat dikelompokkan ke dalam dua bagian pula, yaitu: (1) exposition-discovery learning dan (2) group-individual learning (Rowntree dalam Senjaya, 2008).

\section{STRATEGI METAKOGNITIF}

Salah satu kemampuan penting dalam proses belajar dan pencapaian kompetensi adalah kemampuan metakognitif. Konsep metakognisi telah menjadi sebuah konsep yang sangat populer di dunia pendidikan, meski belum terlalu banyak diteliti di Indonesia.

Flavell (dalam Cautinho, 2008) menyatakan bahwa metakognitif merupakan pengetahuan seseorang terhadap proses berpikirnya sendiri. Dengan kata lain, metakognitif menggambarkan sebuah proses berpikir untuk berpikir.

Sehingga, ketika seorang pebelajar telah memiliki kemampuan metakognitif yang memadai, ia akan mampu menjalani proses belajarnya dengan lebih baik untuk memperoleh hasil yang lebih baik pula.

Fogarty (dalam Pantiwati, 2015: 31) menunjukkan bahwa metakognisi adalah proses yang mencakup tiga tahap yang berbeda, dan untukmenjadi pemikir yang berhasil, siswa harus melakukan hal berikut:1). Mengembangkan rencana sebelum melakukan pembelajaran, seperti membaca untuk pemahaman atau memecahkan masalah, 2). Memantau pemahaman dengan menggunakan strategi ketika memecah masalah, 3) mengevaluasi pemikiran siswa setelah menyelesaikan tugas.

Berdasarkan beberapa pengertian metakognitif beberapa ahli di atas disimpulkan bahwa metakognitif adalah suatu kesadaran tentang kognitif kita sendiri, bagaimana kognitif kita bekerja serta bagaimana mengaturnya. Kemampuan ini sangat penting terutama untuk keperluan efisiensi penggunaan kognitif kita dalam menyelesaikan masalah. Secara ringkas metakognitif dapat diistilahkan sebagai "thinking about thingking”.

\footnotetext{
${ }^{4}$ Dick, Walter. Lou Carey, James O. Carey. 2009.The Systematic Design of Instruction. Fifth edition.

${ }^{5}$ Wina Senjaya. 2008. Strategi Pembelajaran; Berorientasi Standar Proses Pendidikan. Jakarta: Kencana Prenada Media Group.
} 


\section{METODE PQ4R}

Thomas dan Robinson (dalam Wangka \& Usman, 2016:70) mengungkapkan bahwa salah satu strategi yang paling banyak dikenal untuk membantu siswa memahami dan mengingat materi yang dibaca adalah strategi PQ4R. ${ }^{6}$

Thomas dan Robinson menjelaskan bahwa beberapa langkah - langkah yang harus dilakukan dalam startegi pembelajaran PQ4R adalah: (1). Preview, langkah pertama ini dimaksud agar siswa membaca selintas dengan cepat. (2). Question, langkah kedua yaitu mengajukan pertanyaan- pertanyaan pada diri sendiri untuk setiap pasal yang ada pada siswa. (3). Read, yaitu baca buku dan bahan bacaan lainnya dengan efektif, yakni dengan cara, pikiran siswa harus memberi reaksi terhadap apa ynag dibacanya. (4). Reflection (refleksi).

\section{PERAN METAKOGNITIF BAGI MAHASISWA}

Perkembangan yang optimal pada segala aspek merupakan faktor kesuksesan seseorang kedepan. Pola pengasuhan dan pendidikan yang dilakukan oleh orang tua, guru dan lingkungan akan berpengaruh terhadap kualitas anak. Dengan tanpa mengabaikan aspek lain, perkembangan kognitif menjadi salah satu fokus penting selain perkembangan fisik pada masa anak-anak.

Seiring dengan peningkatan kemampuan kognitif, anak mulai menyadari bahwa pikiran terpisah dari objek atau tindakan seseorang. Anak sudah dapat mulai mengatur pikirannya dalam bentuk yang sederhana. Berdasarkan penelitian Flavel, anak 3 tahun memiliki kemampuan untuk mengatur pikirannya. Kemampuan inilah yang disebut metakognitif, yaitu suatu kesadaran tentang kognitif kita sendiri, bagaimana kognitif kita bekerja serta bagaimana mengaturnya. Kemampuan ini sangat penting terutama untuk keperluan efisiensi penggunaan kognitif kita dalam menyelesaikan masalah. Secara ringkas metakognitif dapat diistilahkan sebagai "thinking about thingking".

Mahasiswa dapat menggunakan strategi metakognitif dalam pembelajaran meliputi tiga tahap berikuti, yaitu : merancang apa yang hendak dipelajari; memantau perkembangan diri dalam belajar; dan menilai apa yang dipelajari. Strategi metakognitif dapat digunakan untuk setiap pembelajaran bidang studi apapun. Hal ini penting untuk mengarahkan mereka agar bisa secara sadar mengontrol proses berpikir dalam pembelajaran. Untuk meningkatkan kemampuan metakognitif mahasiswa, guru atau dosen dapat merancang pembelajaran berkaitan dengan kemampuan metakognitif tetapi secara infuse/tambahan dalam pembelajaran atau bukan merupakan pembelajaran yang terpisah.

\footnotetext{
${ }^{6}$ Wangka, A \& Usman, M.(2016). Penerapan Strategi Pembelajaran Pq4r (Preview, Question, Read, Reflect,Recite, Dan Review) Dalam Meningkatkan Prestasi Belajar Pai. Makasar: Jurnal Tarbawi| Volume 1|No 1| ISSN 2527-4082
} 


\section{METODE PENELITIAN}

Berdasarkan permasalahan yang muncul, maka penelitian ini menggunakan pendekatan kualitatif. Menurut Sugiono (2014:11) Metode penelitian kualitatif merupakan metode penelitian yang berlandas-kan pada filsafat positivisme, digunakan untuk meneliti pada kondisi obyek yang alamiah, (sebagai lawannya adalah eksperimen) dimana peneliti adalah sebagai instrumen kunci, pengambilan sampel sumber data dilakukan secara purposive dan snowbaal, teknik pengumpulan dengan trianggulasi, analisis data bersifat induktif/kualitatif, dan hasil penelitian kualitatif lebih menekan makna dari pada generalisasi.

Desain penelitian ini adalah penelitian kualitatif deskriptif. Metode deskriptif adalah suatu metode dalam meneliti status sekelompok manusia, suatu objek, kondisi, sistem pemikiran ataupun peristiwa pada masa sekarang. Tipe penelitian ini berusaha menerangkan fenomena sosial tertentu. Penelitian dapat dibedakan menjadi beberapa jenis, berdasarkan kriteria pem-bedaan antara lain fungsi akhir dan pendekatannya. Menurut Singarimbun (1989:4), "penelitian deskriptif dimaksudkan untuk pengukuran yang cermat terhadap fenomena sosial tertentu, misalnya perceraian, pengangguran, keadaan gizi, preferensi terhadap politik tertentu dan lain-lain".

Pada penelitian ini terdapat dua variabel yaitu variabel bebas atau independen (X) dan variabel tidak bebas atau dependen (Y). Variabel dependen (Y) adalah variabel yang dijelaskan atau yang dipengaruhi oleh variabel independen $(\mathrm{X})$. Pada penelitian ini variabel independen adalah (X1) strategi metakognitif, (X2) metode PQ4R, sedangkan variabel dependen (Y) Prestasi akademik. Subjek penelitian atau responden adalah pihak-pihak yang dijadikan sebagai sampel dalam sebuah penelitian. Subjek penelitian juga membahas karakteristik subjek yang digunakan dalam penelitian, termasuk penjelasan mengenai populasi, sampel dan teknik sampling (acak/non-acak) yang digunakan. Subjek pada penelitian ini adalah seluruh mahasiswa PIAUD semester V IAI Sunan Giri Bojonegoro tahun pelajaran 2018/2019.

\section{PEMBAHASAN}

Sebelum melakukan penelitian dengan menerapkan strategi metakognitif berbantuan metode PQ4R peneliti membandingkan prestasi belajar kognitif mahasiswa tanpa menggunakan metode PQ4R dengan setelah melakukan kegiatan perkuliahan dengan metode PQ4R. Berdasarkan hasil data yang telah dikumpulkan peneliti didapatkan bahwa ada perbedaan yang signifikan pada prestasi akademik mahasiswa khususnya pada mata kuliah kognitif.

Berdasarkan hasil wawancara dan pengambilan angket dan dari beberapa data diperoleh bahwa strategi metakognitif berbantuan PQ4R memiliki peran terhadap prestasi akademik mahasiswa. Untuk lebih jelasnya hasil analisis angket penerapan strategi metakognitif dengan bantuan metode PQ4R dapat dijelaskan melalui tabel berikut ini: 
Tabel 1. mahasiswa yang menyukai strategi metakognitif dengan bantuan metode PQ4R

\begin{tabular}{|c|l|c|c|}
\hline No & Alternatif Jawaban & Frekuensi & $\begin{array}{c}\text { Persentasi } \\
(\%)\end{array}$ \\
\hline 1 & Kadang-kadang & 5 & $11,63 \%$ \\
\hline 2 & Ya & 38 & $88,37 \%$ \\
\hline 3 & Tidak & 0 & $0 \%$ \\
\hline \multicolumn{2}{|c|}{ Jumlah } & $100 \%$ \\
\hline
\end{tabular}

Tabulasi angket no.1

Berdasarkan tabulasi angket dapat diketahui bahwa mahasiswa yang menyukai strategi metakognitif dengan bantuan metode PQ4R sebanyak 38 mahasiswa $(88,37 \%)$, yang menyatakan kadang-kadang 5 mahasiswa $(11,63 \%)$ dan yang tidak menyukai sebanyak nol mahaiswa (0\%). Sehingga peneliti menyimpulkan bahwa mayoritas mahasiswa menyukai pelaksanaan perkuliahan dengan menggunakan strategi metakognitif berbantuan metode PQ4R. Selain itu juga penggunaan strategi metakognitif berbantuan metode PQ4R dapat meningkatkan prestasi akademik khususnya mata kuliah kognitif mahasiswa.

Penerapan metode ini dosen harus memiliki kreatifitas tinggi dalam menyampaikan mteri yang dapat membangkitkan motivasi belajar mahasiswa. Sehingga dalam kegiatan perkuliahan mahasiswa tidak canggung untuk mengembangkan potensi dirinya di dalam kelas. Bagaimanapun juga penerapan strategi metakognitif berbantuan meted PQ4R memungkinkan mahasiswa untuk memiliki kreativitas atau kemampuan dalam membaca, menelaah dan lebih aktif didalam kelas. Baik dalam menyampaikan pendapat atau menjawab pertanyaan.

Penggunaan strategi PQ4R mahasiswa mengembangkan rencana sebelum melakukan pembelajaran, seperti membaca untuk pemahaman atau memecahkan masalah, 2). memantau pemahaman dengan menggunakan strategi ketika memecah masalah, 3) mengevaluasi pemikiran siswa setelah menyelesaikan tugas.

Penerapan strategi metakognitif berbantuan metode PQ4R merupakan hal yang baru bagi mahasiswa PIAUD Institut Agama Islam Sunan Giri Bojonegoro dan belum pernah diterapkan didalam perkuliahan sebelumnya, sehingga tugas dosen adalah menumbuhkan minat belajar mahasiswa pada mata kuliah kognitif terutama membaca, dalam penerapan strategi ini menuntut mahasiswa untuk terampil dalam membaca materi yang diberikan dosen. Sehingga mahasiswa memiliki kepercayaan diri untuk bertanya, menjawab dan mengutarakan pendapatnya sehingga meningkatkan keaktifan mahasiswa dalam proses perkuliahan.

Keaktifan mahasiswa pada penerapan strategi metakognitif berbantuan metode PQ4R sangat mempengaruhi peningkatan prestasi akademik mahasiswa, hal tersebut terbukti dengan meingkatnya hasil prestasi akademik pada mata kuliah 
kognitif dari nilai tes sebelum menggunakan metode PQ4R dan sesudah menggunakan. Sehingga dalam hal ini peneliti dapat menyimpulkan bahwa penerapan strategi metakognitif berbantuan metode PQ4R prestasi akademik mahasiswa berkembang secara signifikan.

\section{DAFTAR PUSTAKA}

Arifin, M. (2017). Strategi Manajemen Perubahan Dalam Meningkatkan Disiplin Di Perguruan Tinggi. Medan: Jurnal EduTech Vol. 3 No. 1 Maret 2017 ISSN: 24426024, hal 127

Arikunto, S. (2010). Prosedur Penelitian Suatu Pendekatan Praktek. Jakarta: PT Rineka Cipta.

Coutinho, S. (2008). Self-Efficacy, Metacognition, and Performance. North American: Journal of Psychology; Winter Garden, Vol. 10, Iss. 1, (Mar 2008): 165-172.

Creswell, J. (2012). Reserch Design Qualitative, Quantitative and Mixed Methods Approach. Singapore: Asia Pacific Pte. Ltd

Dick, Walter. Lou Carey, James O. Carey. 2009.The Systematic Design of Instruction. Fifth edition.

Fitri,M. (2017). Metakognitif Pada Proses Belajar Anak Dalam Kajian Neurosains.Surabaya: Jurnal Pendidikan Volume 2 Nomor 1 Tahun 2017 Halaman: 44-52 e-ISSN: 2527-6891.

Kasyani, T, Y. (2012). Efektivitas Strategi Metakognisi terhadap Keterampilan Berpikir pada pelajran Fisika di SMA N 6 Balikpapan. (Tesis). Universitas Negeri Malang.

Restuadyani, S. (2015). Efektivitas Strategi Metakognitif Berbantuan Isomorphic Problems terhadap Kemampuan Pemecahan Masalah Fisika Ditinjau dari Kemampuan Metakognitif Siswa Kelas X. (Tesis). Universitas Negeri Malang.

Sugiyono. (2014). Metode Penelitian Kombinasi Mixed Methods. Bandung:Alfabeta.

Wahyudin, Agustin. (2012). Penilaian Perkembangan Anak Usia Dini, Panduan untuk guru, tutor, fasilitator dan pengelola pendidikana anak usia dini. Bandung: Pt. Refika Aditama.

Wangka, A \& Usman, M.(2016). Penerapan Strategi Pembelajaran Pq4r (Preview, Question, Read, Reflect,Recite, Dan Review) Dalam Meningkatkan Prestasi Belajar Pai. Makasar: Jurnal Tarbawi| Volume 1|No 1| ISSN 2527-4082

Wina Senjaya. 2008. Strategi Pembelajaran; Berorientasi Standar Proses Pendidikan. Jakarta: Kencana Prenada Media Group. 